\title{
Communications
}

\section{An Efficient Oxidation of 1,4-Dihydropyridines to Pyridines Using Silver Carbonate on Silica Gel and Celite}

\author{
Ahmad Reza Momeni." Tayebeh Sameh. Hosein Golmohammadi, Hamid Javaherian Naghash, \\ Hamid Alyan. Ahmad Reza Massah, and Shirin Solati

\begin{abstract}
Department of Chemistry, Islamic Azad Cniversity Shahreza Branch, 86145-311, Isfahan, Iran. 'E-mail: momenialaushac ir Received September 9. 2005
\end{abstract}

Key Words : 1,4-Dihydropyridines, Silver carbonate, Oxidation, Celite, Silica gel

The oxidation of Hantzsch 1,4-dihydropyridines to the corresponding pyridines has been extensively studied in view of the pertinence of the reaction to the metabolism of Hantzsch esters and the calcium channel blocking drugs used in the treatment of various cardiovascular disorders. The reaction has also been used to study the biologically significant NADH redox processes. ${ }^{2}$ Consequently, this aromatization reaction continues to attract the attention of researchers for the discovery of milder and general protocols applicable to a wide range of 1,4-dihydropyridines. Several oxidizing agents and methods such as $\mathrm{KMnO}_{4},{ }^{3}$ solid supported pyridiuium chlorochromate $(\mathrm{PCC})^{+}$silica gel supported ferric nitrate, ${ }^{5}$ nitric oxide, ${ }^{6} \mathrm{MnO}_{3}{ }^{7}$ ceric ammonium nitrate (CAN), tert-butylhydroproxide, clay supported cupric nitrate, ${ }^{10} \mathrm{Bi}\left(\mathrm{NO}_{3}\right)_{3},{ }^{11} \mathrm{I}_{2} / \mathrm{MeOH}_{4}{ }^{12} \mathrm{Zr}\left(\mathrm{NO}_{3}\right)_{4}{ }_{4}^{13}$ tetrakispyridine cobalt(II) dichromate (TPCD), ${ }^{1+}$ iodobernene diacetate, ${ }^{15} \mathrm{NaNO}_{2} / \mathrm{NaHSO}_{4} / \mathrm{SiO}_{2}{ }^{16}$ 3-Carboxypyridinium chlorochromate $(\mathrm{CPCC})^{17} \mathrm{BaMnO}_{4},{ }^{18} \mathrm{~T}\left(\mathrm{NO}_{3}\right)_{3} \cdot 3 \mathrm{H}_{2} \mathrm{O},{ }^{19}$ or photochemical reactions ${ }^{20}$ have been introduced in the literature for this purpose. The introduction of supported reagents for bringing about various chemical transfommations has provided an attractive option for organic synthesis. These reagents not only modify the activity but also may impart product selectivity.

Because of our interest in oxidation processes, we decided to develop a practical and general approach for oxidative conversion of 1,4-dihydropyridines using a mild oxidant, silver carbonate. This reagent is a mild oxidizing agent. This operates under neutral and heterogeneous conditions. Silver carbonate on celite was employed for organic reactions such as oxidation of alcohols, ${ }^{21} 1,2-$ diols, ${ }^{22}$ phenols, ${ }^{23}$ amines and hydrazines. ${ }^{24}$ Silver carbonate on silica gel and celite can be readily available. We wish to indicate that it can also serves as an excellent oxidant for a variety of Hantzsch 1,4dilhydropyridines.

A series of 1,4-DHP derivatives (1-12, Scheme 1) were synthesized $\mathrm{d}^{20.25}$ to investigate their conversion to the corresponding pyridines. Initially 4-phenyl-dibydropyridine (entry 3) has been used as a substrate to test the feasibility of silver carbonate used as an oxidant for DHP's. Investigation on the oxidation efficiency of silver carbonate alone at ambient temperature as well as higher temperature indicated that, oxidation of (3) into aromatized product did not proceed effectively. A better activity of silver carbonate was obtained when combined with silica gel or celite. Silver carbonate on celite as mentioned above is known, but silver carbonate on silica gel was used for the first time in this study. Subsequent experiments revealed that at reflux conditions in acetonitrile a ratio of $\mathrm{DHP}: \mathrm{Ag}_{2} \mathrm{CO}_{3}=1: 6$ on silica gel and $\mathrm{DHP}$ : $\mathrm{Ag}_{2} \mathrm{CO}_{3}=1: 12$ on celite was most effective. Under similar conditions various substituted 1,4-dihydropyridines were efficiently converted to the pyridine derivatives ${ }^{26}$ and the results are given in Table 1.

According to the experinent we observed that oxidation of 1,4-dihydropyridines with secondary alkyl group (entry 5) and benzyl groups (entry 6) at the 4-position were perfomed efficiently and only dealkylated pyridine derivative (13) was obtained. This is a general trend in the oxidation of 1,4dihydropyridines. 1,4-Dihydropyridine (entry 4) with propyl group at the 4-position yielded two products, dealkylated<smiles>[R]C1C(C(=O)OCC)=C(C)NC(C)=C1C(=O)OCC</smiles>

$1-12$

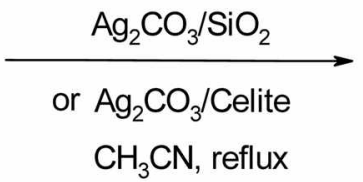

$\mathrm{CH}_{3} \mathrm{CN}$, reflux<smiles>CCOC(=O)c1cc(C(=O)OCC)c(C)nc1C</smiles>

13<smiles>[R]c1c(C(=O)OCC)c(C)nc(C)c1C(=O)OCC</smiles>

$14-22$

Scheme 1 
Table 1. Oxidation of 1,4-Dihydropyridines with Silver Carbonate on Silica gel and Silver Carbonate on Celite

\begin{tabular}{|c|c|c|c|c|c|c|}
\hline \multirow{2}{*}{ Entry } & \multirow{2}{*}{$\mathrm{R}$} & \multirow{2}{*}{ Products } & \multicolumn{2}{|c|}{$\begin{array}{c}\text { Silver } \\
\text { carbonate/SiO= }\end{array}$} & \multicolumn{2}{|c|}{$\begin{array}{c}\text { Silver } \\
\text { carbonate/Celite }\end{array}$} \\
\hline & & & $\begin{array}{l}\text { Time } \\
\text { (h) }\end{array}$ & $\begin{array}{l}\text { Yields } \\
(0.6)^{6}\end{array}$ & $\begin{array}{l}\text { Time } \\
\text { (b) }\end{array}$ & $\begin{array}{l}\text { Yields } \\
(\%)^{h}\end{array}$ \\
\hline 1 & $\mathrm{H}$ & 13 & 0.9 & 99 & 0.5 & 95 \\
\hline 2 & $\mathrm{CH}_{3}$ & 14 & 3.5 & 79 & 5.5 & 98 \\
\hline 3 & $\mathrm{C}_{6} \mathrm{H}_{5}$ & 15 & 1.75 & 94 & 3.5 & 90 \\
\hline 4 & $\mathrm{CH}_{3} \mathrm{CH}_{2} \mathrm{CH}_{2}$ & $13+16$ & 2 & $76-15$ & 3 & $55-20$ \\
\hline 5 & $\left(\mathrm{CH}_{3}\right) \leq \mathrm{CH}$ & 13 & 0.8 & 95 & 5 & 98 \\
\hline 6 & $\mathrm{C}_{6} \mathrm{H}_{5} \mathrm{CH}_{3} \mathrm{CH}$ & 13 & 0.75 & 94 & 2.2 & 95 \\
\hline 7 & $3-\mathrm{NO}_{2} \mathrm{C}_{6} \mathrm{H}_{4}$ & 17 & 5 & 87 & 9 & 90 \\
\hline 8 & $4-\mathrm{NO}_{2} \mathrm{C}_{6} \mathrm{H}_{4}$ & 18 & 5 & 82 & 6.5 & 80 \\
\hline 9 & 2-Pyridyl & 19 & 0.8 & 93 & 8 & 85 \\
\hline 10 & $4-\mathrm{ClC}_{6} \mathrm{H}_{4}$ & 20 & 3 & 96 & 4 & 95 \\
\hline 11 & $4-\mathrm{BrC}_{6} \mathrm{H}_{4}$ & 21 & 3 & 91 & 4 & 80 \\
\hline 12 & $4-\mathrm{CH}_{3} \mathrm{OC}_{6} \mathrm{H}_{4}$ & 22 & 1.5 & 98 & 5 & 98 \\
\hline
\end{tabular}

"All products wete characterized by ${ }^{1} H-$ NMR, IR and their m.p.s. Compared with literature values. "Isolated yields

compound (13), which is rarely observed by primary alkyl groups, and pyridine derivative (16) with retention of 4 substituent. However, 4-methyl, 4-aryl and 4-heteroaryl-1,4dihydropyridines (entries 2, 3 and 7-12) were oxidized with retention of substitution at 4-position to afford the corresponding pyridines (14-22) in good to excellent yields. In comparison with silver carbonate on celite, silver carbonate on silica gel is more reactive.

The effect of different solvents on the oxidation reaction was investigated. In comparison with acetonitrile, the reaction time was longer and the yields of products were considerably lower when dichloromethane, carbontetrachloride and chloroform were employed as a solvent.

In summary, we have found that silver carbonate on silica gel or celite is a valuable addition to the existing methods available for the oxidation of 1,4-dihydropyridines whit additional advantages of ease of procedure, workup and high yields.

\section{References}

1. (a) Janis, R. A.; Triggle, D. J. J. Med. Chem. 1983, 26, 775. (b) Gordeev, M. F.; Palel, D. V; Gordon, E. M. J. Org. Chem, 1996, 61, 924. (c) Bossert, F,; Vater, W. Med. Res. Rev. 1989, 9, 291.

2. Stout, D. M.; Meyers, A. I. Chem. Rev. 1982, 82, 223.

3. Vanden Eynde, J. I.; D'Orazio, R.; Van Haverbeke, Y. Tetrahedron $1994,50,2479$.

4. Vanden Eynde, J. J.; Mayence, A.; Maquestiau, A. Tetrohedron $1992,48,463$.

5. Khadikar, B.; Brokar, S. Synth. Commm 1998,2S, 207.

6. Itoh, T.; Nagata, K.; Matsuya, Y:: Miyazaki, M.: Ohsawa, A. $J$. Org. Chen. 1997, 62, 3582 .
7. Vanden Eynde, J. J.; Delfosse, F.: Mayence, A.; Van Haverbeke, Y. Tetrahedron 1995, 5/,6511.

8. Pfister, J. R. Syrthesis 1990,689

9. Chavan, S. P.; Dantal, S. W.; Kalkote, U. R.; Jyothimai, V. S.; Kharul, R. K. Symh. Conmmon, 1998, 28, 2789.

10. Maquestion, A.: Mayence, A.: Vanden Eynde, J. J. Tetrahedron Lett. 1991, 32, 3839 .

11. Mashraqui, S. H.; Kanik, M. A. Syrthesis 1998, 713.

12. Yaday, J. S.; Subba Reddy, B. V.; Sabita, G.; Kiran Kunnar Ready, G. S. Syrthesis $2000,1532$.

13. Sabita, G.: Kiran Kumar Ready, G. S.: Srinivas, Ch.: Fatima, N.: Yadav, J. S. Symthesis $2003,1267$.

14. Wang, B.: Hu, Y.: Hu, H. Symth. Commin. 1999, $29,4193$.

15. Cheng, D. P.; Chen, Z. C. Sy wh. Commum. 2002,32, 793.

16. Zolfigol, M. A.; Kiany-Borazjani, M.; Sadeghi, M. M.; Meınarian, H. R.; Mohaminadpoor-Baltork, I. Sinth. Commur. 2000, 30 , 2945.

17. Mohammadpoor-Baltork, J.; Sadeghi, M. M.; Memarian, H. R.; Pairow, R. J. Chem. Research is $\mathbf{2 0 0 0 , 4 0 .}$

18. Memarian, H. R.; Sadeghi, M. M.; Momeni, A. R. Symth. Commutr. 2001, 31, 2241.

19. Momeni, A. R.; Massah, A. R.; Javaherian Naghash, H.; Aliyan, H.: Solati, S.: Sameh, T. J. Chen. Resemch $2005,227$.

20. (a) Memarian, H. R.; Sadeghi, M. M.; Monneni, A. R. Indian J. Chem. 1999, 3SB, 800, (b) Memarian, H. R.: Sadeghi, M. M.; Momeni, A. R. Moratshefte fut Chemie. 2002, 133, 661. (c) Memarian, H. R.; Sadeghi, M. M.; Momeni, A. R. Irdian $J$. Chem. 2001, 40B, 508 .

21. (a) Schwab, J. M.; Chorng-Kei, H. J. Chem. Soc. Chem. Conmmn. 1989, 872. (b) Gardner, D.: Glen, A. J.: Tumer, W. B.: Dimitriadis, E.: Massy-Westropp, R. A. Aust. J. Chem, 1980, 33, 2729.

22. (a) Corey, E. J.; Ueda, Y.; Rudew, R. A. Tetrahedron Lett. 1975. 4347. (b) Daily, O. D. Jr.; Fuchs, P. L. J. Org. Chem. 1980, 45, 216.

23. Balogh, V.; Fetizon, M.; Golfier, M. J. Org. Chem. 1971, 36, 1339.

24. Hedayatllah, M.: Dechatre, J. P.: Denivelle, J. P. Tetrahedron Lett. 1975,2039

25. Love, B.; Goodınan, M. M.; Snader, K. M.; Tedeshi, R.; Macko, E. J. Med. Chem 1974, 19,956.

26. Silver carbonate is commercially available and prepared according to the following procedure.

Prepanation of solid-stipported siher cambonate: \$ilver nitrate ( 30 g) is dissolved in $200 \mathrm{~mL}$ of distilled water, and silica gel ( $30 \mathrm{~g}$ ) is added. To the stirred mixture, a solution of sodium carbonate $\left(\mathrm{Na}_{2} \mathrm{CO}_{3}, 10 \mathrm{H}_{2} \mathrm{O}\right)(30 \mathrm{~g})$ in distilled water $(300 \mathrm{~mL})$ is slowly added. The yellow-green precipitate is filtered and washed to neutrality with distilled water. It is then dried $(4 \mathrm{~h})$ by rotatory evaporation on a steam bath, preferably in the dark. When prepared according to this procedure, $0.6 \mathrm{~g}$ of this reagent contains approximately I minol of $\mathrm{Ag}_{2} \mathrm{CO}_{3}$.

Oxidation of I 4-dihydropyridines with sither carbonate on silica gel: general procedne: A suspension of 1,4-dihydropyridines $(0.2 \mathrm{mmol})$ and silica gel supported silver carbonale $(0.72 \mathrm{~g})$ in acetonitrile ( $10 \mathrm{~mL}$ ) was stirted at reflux condition for the time indicated in Table I. The progress of the reaction was inonitored by TLC. The mixture was filtered and then washed with acetonitrile. The filtrate was evaporated, the product obtained was recrystalized with ethanol. Products of entry 4 were purified by TLC.

Oxidation of 1,4-dihydropyridines with silver carbonate on celite Same procedure as above method but with $1.4 \mathrm{~g}$ celite supported silver carbonate. 